\title{
Growth response of an invasive alien species to climate variations on subantarctic Campbell Island
}

\author{
J.G. Palmer ${ }^{1,2 *}$, C.S.M. Turney ${ }^{1,2}$, C. Fogwill ${ }^{3}$, P. Fenwick ${ }^{4}$, Z. Thomas ${ }^{1,2}$, M. Lipson ${ }^{2}$, R.T. Jones ${ }^{5}$, \\ B. Beaven ${ }^{6}$, S.J. Richardson ${ }^{7}$ and J.M. Wilmshurst ${ }^{7,8}$ \\ ${ }^{1}$ Palaeontology, Geobiology and Earth Archives Research Centre, School of Biological, Earth and Environmental Sciences, \\ University of New South Wales, NSW 2052, Australia \\ ${ }^{2}$ Climate Change Research Centre, School of Biological, Earth and Environmental Sciences, University of New South Wales, \\ NSW 2052, Australia \\ ${ }^{3}$ School of Geography, Geology and the Environment, William Smith Building, Keele University, Staffordshire, ST5 5BG, UK \\ ${ }^{4}$ Gondwana Tree-Ring Laboratory, PO Box 14, Little River, Canterbury 7546, New Zealand \\ ${ }^{5}$ Department of Geography, Exeter University, Devon, EX4 4RJ, UK \\ ${ }^{6}$ Conservation House, PO Box 10420, Wellington 6143, New Zealand \\ ${ }^{7}$ Landcare Research, PO Box 69040, Lincoln 7640, New Zealand \\ ${ }^{8}$ School of Environment, University of Auckland, Private Bag 92019, Auckland 1142, New Zealand \\ *Author for correspondence (Email: j.palmer@unsw.edu.au)
}

Published online: 27 November 2017

\begin{abstract}
Invasive alien species (IAS) are a recognised threat to biodiversity and ecosystem services. With increasing tourism and projected 21 st century climate changes across the mid- to high-latitudes of the southern hemisphere, subantarctic islands are potentially highly vulnerable to IAS, but suffer from a dearth of baseline monitoring. Here we report tree-ring measurements from a lone exotic Sitka spruce (Picea sitchensis (Bong.) Carr) on subantarctic Campbell Island to determine past growth rates and likely future response to climate changes. Though the samples were unable to resolve exactly when the tree was planted, the fast growth rate indicates it is likely to have been later than the reported date of 1901. Since at least 1941, the tree appears to have responded favourably to the relatively warm summers experienced on Campbell Island, resulting in growth more rapid than that observed in natural stands (North American Pacific Coast). Although trees of similar age are normally mature and produce cones, none have so far been observed on Campbell Island - possibly the result of the fast growth causing an extended 'juvenile' or pre-reproductive phase-preventing seeding across the island. Importantly, relatively dry periods are needed for cones to open and disperse seeds, conditions not recorded in the instrumental record. Examination of the Coupled Model Intercomparison Project 5 (CMIP5) outputs show increasing rainfall across the region during the 21 st century under a range of emission scenarios, suggesting that even when mature, the Sitka spruce poses a limited threat to the long-term ecology of Campbell Island.
\end{abstract}

Keywords: Campbell Island; exotic forestry trees; invasive alien species; Picea sitchensis; Sitka spruce; subantarctic islands; tree-ring

\section{Introduction}

Invasive alien species (IAS) are defined as 'a species that is established outside of its natural past or present distribution, whose introduction and/or spread threaten biological diversity' (IUCN 2016) and are increasingly recognised as a threat to global biodiversity, ecosystem services and human health (Walther et al. 2009; McGeoch et al. 2010; Early et al. 2016). The threat is likely to increase on subantarctic islands that are projected to experience substantial climate changes over the next century (Whittaker \& Fernández-Palacios 2007; Kueffer et al. 2010; Lebouvier et al. 2011) and may act as 'stepping stones' across the Southern Ocean to the Antarctic continent (Frenot et al. 2005; Gregory 2009; Lee \& Chown 2009; Nikula et al. 2010; Chown et al. 2012; Hughes \& Convey 2012; McGeoch et al.2015). While palaeoecological studies provide important insights into the timing and ecological impact(s) of IAS (Wilmshurst et al. 2015), there are few baseline measurements of growth response to climate in these remote islands.

Annually formed tree-rings in exotic species used for commercial forestry and agroforestry provide an opportunity to investigate long-term growth under climate regimes far removed from their original (natural) environment (Richardson 1998). The solitary Sitka spruce (Picea sitchensis (Bong.) Carr) on subantarctic Campbell Island (Fig. 1) provides an excellent case study in this regard. In 1989, a plaque was placed by Governor General Sir Paul Reeves next to the tree stating it was planted in 1901 by Lord Ranfurly, Governor of New Zealand (hence it is known as the 'Ranfurly tree'). A more common reference by tourist operators in the region is 'the world's loneliest tree', applied after a supposedly drunken truck driver killed the previous candidate, the Tree of Ténéré in 1973 (or l'Arbre du Ténéré) in Niger Sahara (Anonymous 1974). The moniker that the Sitka spruce is the sole tree on Campbell Island ignores the fact that there is no universally recognised precise definition of what is a 'tree', either botanically or in common usage, and that some large local native shrubs of Dracophyllum scoparium and D. longifolium can attain heights over $5 \mathrm{~m}$ in sheltered situations and so could also be reasonably regarded as trees (Harsch et al. 2014; Turney et al. 2017). Meurk and Given (1990) and Meurk et al. (1994) have used the term 'dwarf forest' or elfin woods to describe such vegetation. 


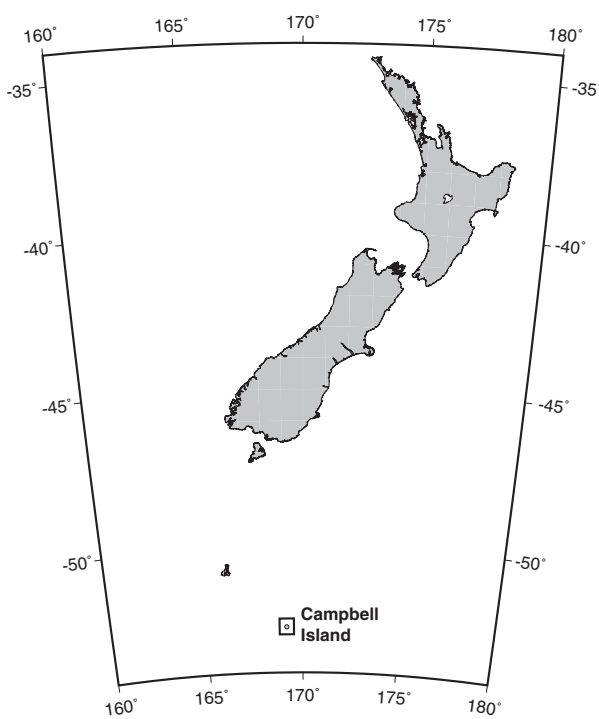

B.

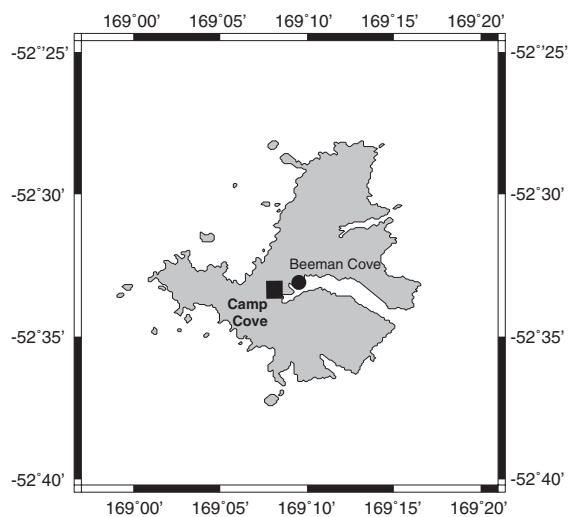

c.

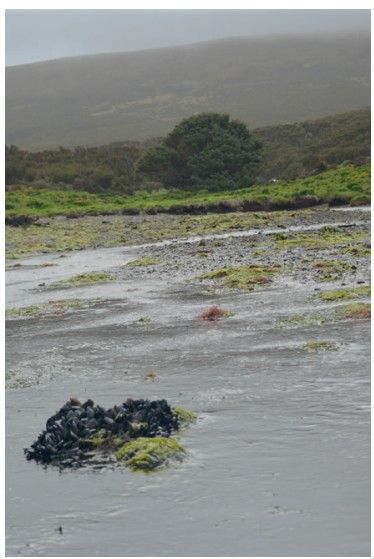

Figure 1. Location of subantarctic Campbell Island, southwest Pacific (Panel A.) and the Sitka spruce in Camp Cove (Panel B.). Photograph of the Sitka spruce shown in Panel C.

Sitka spruce is found naturally along the western part of North America, occurring in a narrow coastal belt running along the Pacific Coast from Alaska to California (Harlow et al. 1978). The species tends not to occur very far inland or far above sea level and is generally regarded as a fast-growing species of high productivity. This restricted distributional area reflects a preference for a maritime climate with relatively mild winters and cool summers. The meteorological station at Beeman Cove, Perseverance Harbour, shows that Campbell Island experiences broadly similar maritime temperature conditions with uniform precipitation across the year (New Zealand National Climate Database, http://cliflo.niwa.co.nz/). Annual rainfall is $1376 \pm 142 \mathrm{~mm} \mathrm{yr}^{-1}$, with mean winter (JuneAugust) and summer (December-February) temperatures of $5^{\circ} \mathrm{C}$ and $9.2^{\circ} \mathrm{C}$ respectively (1941-2015). In this paper, we aim to identify how well the tree has grown since establishment and the implications for its potential spread under a range of future climate change scenarios.

\section{Methods}

The Campbell Island Sitka spruce is located in Camp Cove at $52.554^{\circ} \mathrm{S}, 169.133^{\circ} \mathrm{E}$ (c. $3 \mathrm{~m}$ above sea level). The tree is approximately $10 \mathrm{~m}$ tall and has a wide, spreading crown comprised of multiple branches, several of which start from near ground level (Fig. 1). The crown shows clear signs of wind shear from the prevailing westerly winds. The extent of branching increases the difficulty of coring and being able to reach the centre of the tree. Increment core samples were collected on two occasions. Two cores from a large lateral branch were taken in 2013 during the Australasian Antarctic Expedition 2013-2014, and a further four cores were taken during fieldwork in late 2014. Details of the samples are:

- two from a major branch (centre was 1946)

- two from the central leader (centre was 1941) at $2.3 \mathrm{~m}$ height (DBH $55 \mathrm{~cm}$ )

- two from opposite sides close to the base (north and south at c. $0.4 \mathrm{~m}$ height, neither of which reached the centre of the tree).
All the samples were first dried then glued onto core mounts and sanded using progressively finer grades of sandpaper to produce a highly-polished surface. The cores were then studied under a binocular microscope and the associated ring patterns cross-dated to ensure the samples captured a reliable record of growth, with no missing rings or years identified; a prerequisite for the development of a tree-ring chronology (Stokes \& Smiley 1968). Every tree-ring was measured to the nearest $0.001 \mathrm{~mm}$ using a Velmex measuring stage (www.velmex.com) linked to computer facilities and the measurement series of each core was then standardised to remove biological trends using the dplR program library in R (Bunn 2008, 2010; R Core Team 2015). Within the program, various options are available for the conversion of the annual ring-width measurements into indices and we adopted the use of a more flexible regression model, Friedman's Super Smoother (Friedman 1984), to remove the growth trends. All six series were then combined to produce a single tree 'chronology' (normally multiple trees are combined to produce a chronology).

The species has been successfully used in tree-ring research (Grissino-Mayer 1993) with 45 tree-ring collection sites listed on the International Tree-Ring Data Bank (ITRDB; www.ncdc. noaa.gov/data-access/paleoclimatology-data/datasets/treering). For the sake of comparison, we chose three sites from the ITRDB collection considered to represent the latitudinal span of the species range for comparison to our ring-width measurements obtained from the Campbell Island tree (Table 1). In New Zealand, three other Sitka spruce trees have been registered as notable trees (www.notabletrees.org.nz) and their growth information is included in Table 1.

The relationship of the tree-ring chronology to the Campbell Island temperature record was explored using bootstrapped correlation function analysis in the bootRes library package in R (Fig. 2; Zang \& Biondi 2013; R Core Team 2015). The program uses 1000 bootstrapped samples to compute Pearson's correlation coefficients between the tree-ring parameter and each of the climatic predictors (i.e. monthly temperatures) and then to test their significance at the 0.1 level (shown as darker bars in Fig. 2).

During the process of cross-matching the ring-width 


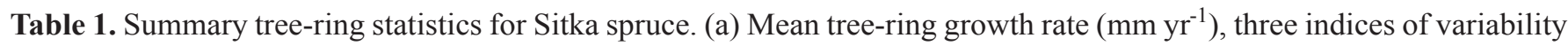
(the standard deviation (SD), the skewness and the Gini coefficient) and a measure of temporal autocorrelation (AR1; the autoregressive process with a lag of one year) for the solitary Campbell Island tree and three other natural stands in Alaska (www.ncdc.noaa.gov/data-access/paleoclimatology-data/datasets/tree-ring). (b) Size and mean growth rate (mm $\mathrm{yr}^{-1}$ ) for three trees registered as notable trees (www.notabletrees.org.nz) in the Wellington Botanic Gardens and Ormond Road, Hastings, New Zealand.

a)

\begin{tabular}{ccccccccc} 
Site & Latitude & $\begin{array}{c}\text { Number of } \\
\text { trees/cores }\end{array}$ & $\begin{array}{c}\text { Mean } \\
\left(\mathrm{mm} \mathrm{yr}^{-1}\right)\end{array}$ & Median & SD & Skew & Gini & AR1 \\
\hline $\begin{array}{c}\text { Campbell Island } \\
\begin{array}{c}\text { Prince of Wales } \\
\text { Island, Alaska }\end{array}\end{array}$ & $52.55^{\circ} \mathrm{S}$ & $1 / 6$ & 4.35 & 4.00 & 2.10 & 0.76 & 0.25 & 0.71 \\
$\begin{array}{c}\text { Russel Fjord, } \\
\text { Alaska }\end{array}$ & $55.29^{\circ} \mathrm{N}$ & $4 / 4$ & 1.96 & 1.91 & 0.56 & 0.59 & 0.16 & 0.80 \\
$\quad \begin{array}{l}\text { Tok River, } \\
\text { Allaska }\end{array}$ & $63.14^{\circ} \mathrm{N}$ & $18 / 18$ & 2.22 & 2.19 & 0.95 & 0.26 & 0.25 & 0.86 \\
& & $6 / 6$ & 0.45 & 0.38 & 0.24 & 1.15 & 0.28 & 0.84
\end{tabular}

\begin{tabular}{lcccccc} 
b) Location & Latitude & $\begin{array}{c}\text { Register } \\
\text { number }\end{array}$ & $\begin{array}{c}\text { Mean } \\
\left(\mathrm{mm} \mathrm{yr}^{-1}\right)\end{array}$ & $\begin{array}{c}\text { Diameter } \\
(\mathrm{cm})\end{array}$ & $\begin{array}{c}\text { Number } \\
\text { of years }\end{array}$ & $\begin{array}{c}\text { Date } \\
\text { established }\end{array}$ \\
\hline $\begin{array}{c}\text { Botanic Gardens, } \\
\text { Wellington }\end{array}$ & $41.28^{\circ} \mathrm{S}$ & WTR/0152 & 5.23 & 136.9 & 131 & c. 1885 \\
$\begin{array}{c}\text { Botanic Gardens, } \\
\text { Wellington }\end{array}$ & $41.28^{\circ} \mathrm{S}$ & WTR/P0374 & 4.23 & 106.6 & 126 & c. 1890 \\
$\begin{array}{c}\text { Hastings Reserve, } \\
\text { Hawkes Bay }\end{array}$ & $39.61^{\circ} \mathrm{S}$ & HBR/P0120 & 6.20 & 168.7 & 136 & c. 1880
\end{tabular}

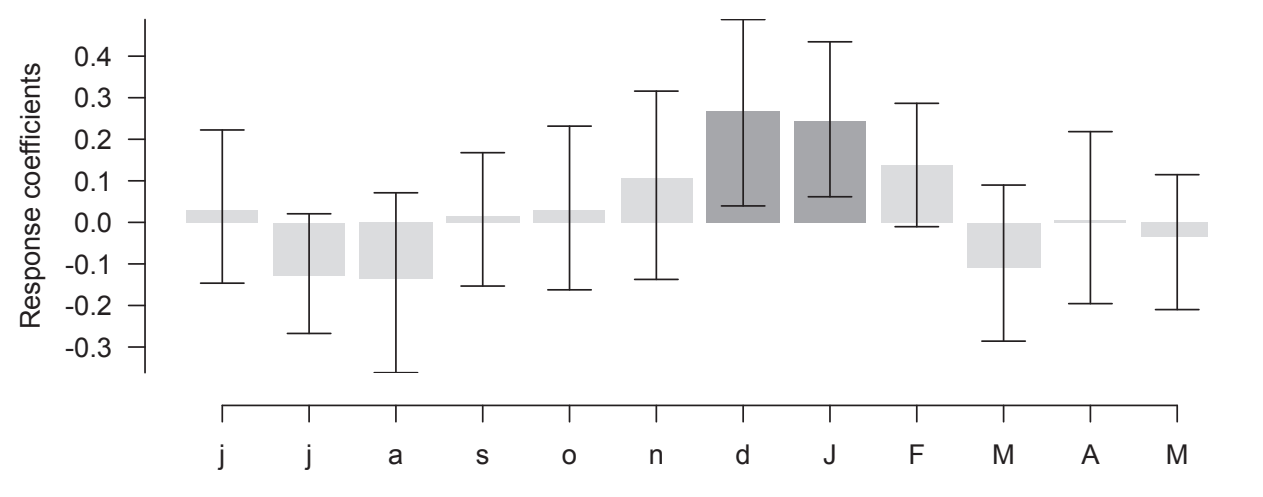

Figure 2. Response function result of Sitka spruce tree-rings to mean monthly temperature from Campbell Island. The 12 monthly correlations start with winter (i.e. June) in one year and extend to the end of autumn (i.e. May) of the following year. The months of the preceding calendar year are shown in lower case while those of the following year are in upper case. The darker bars indicate a Pearson correlation coefficient significant at $\mathrm{P}<0.1$; the lines represent the $90 \%$ confidence interval. patterns and measuring, we observed that many of the cores showed evidence of traumatic resin ducts (Figs. 3 and 4; Stoffel et al. 2010). Traumatic resin ducts (TRDs) can vary anatomically, but in this case, we mainly see tangential rows of cells with phenolic deposits (Schweingruber 2007). Their formation can occur from a variety of different disturbance or stress causes such as temperature extremes (e.g. freezing), mechanical wounding and bending (Wimmer \& Grabner 1997). When TRDs were identified under a light microscope the relative position within each affected tree-ring was measured. The TRD relative positions were then binned into one of four intra-annual growth periods or quarters (Gurskaya et al. 2016).

- The first quarter starts at the beginning of annual growth, right at the zone after the latewood of the previous annual ring. This earlywood section is considered representative of 'spring' growth.
- The second quarter then continues and extends to the first half of the ring and captures the period from late spring to early summer.

- The third quarter represents the late summer period.

- The fourth quarter contains the latewood section and covers autumn growth.

The number of TRDs in each of the quarters was counted and the results presented in Figure 5.

To help explore the possible invasive threat of the Campbell Island Sitka spruce tree and reasons for the lack of any viable cones, the monthly observed precipitation record was investigated to identify possible 'dry' periods that could enable seed dispersion (Fig. 6). The projected change in rainfall for the area was then investigated under two projected future emission scenarios (i.e. Representative Concentration Pathways 2.6 'low' and 8.5 'high' emissions; IPCC 2013) (Fig. 7). 


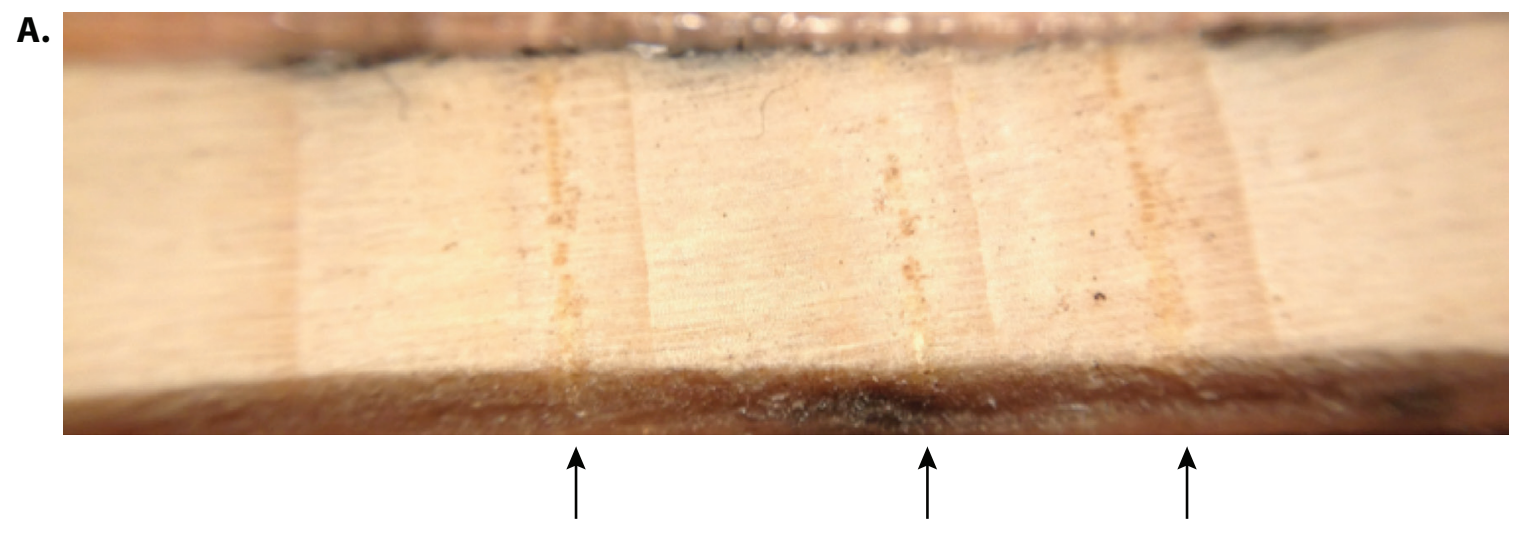

B.

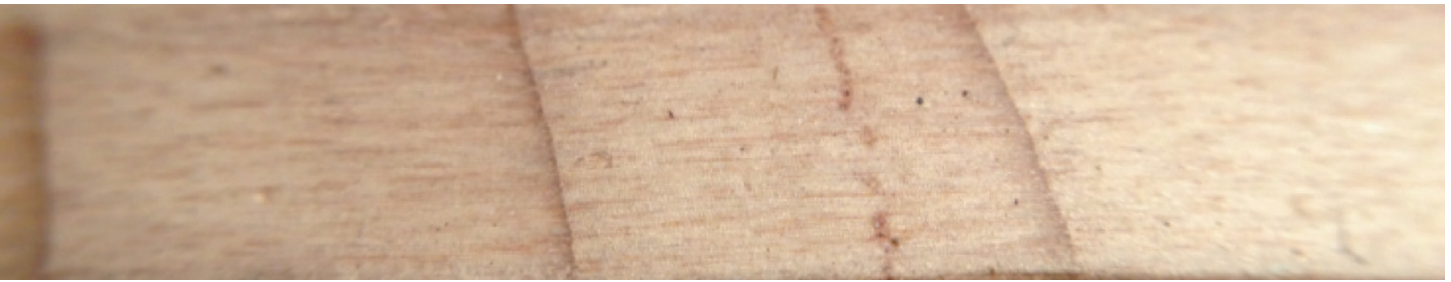

$\uparrow$

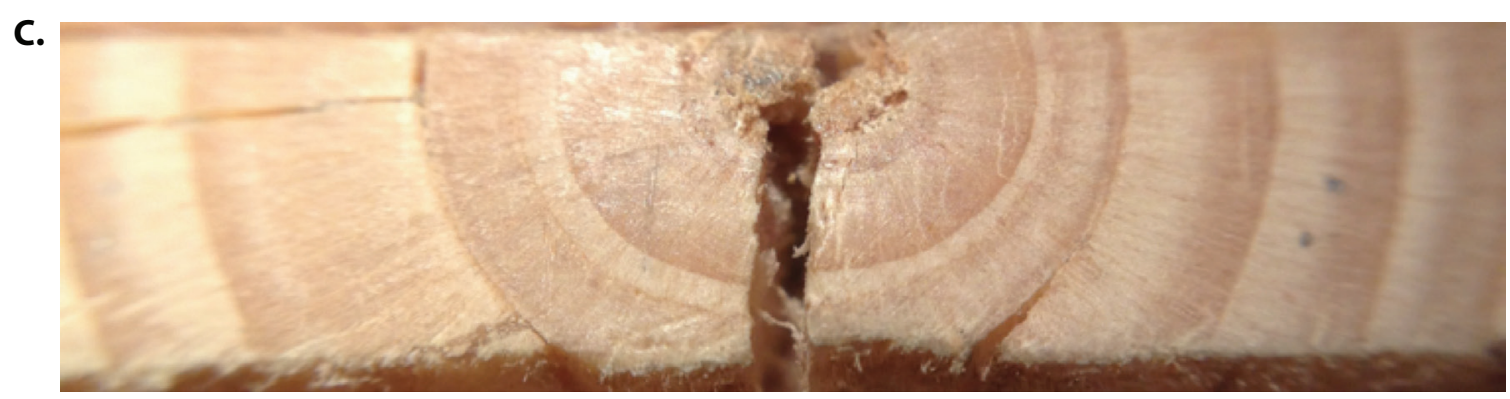

Figure 3. Examples of TRDs observed in the Sitka spruce cores. Arrows indicate TRDs while normal annual ring boundaries are seen as dark lines (growth direction is from left to right in A and B). In the bottom panel (C) the centre or pith of the tree is clearly visible.

\section{Results and discussion}

The core samples from the Campbell Island Sitka spruce establish the tree was only $2.3 \mathrm{~m}$ tall in 1941 but, using treering samples from this study, we are unable to confirm the exact date the tree was planted. Various accounts in botanical expedition reports and interviews conducted by Norm Judd (pers. comm.) do not provide an exact date, with estimates ranging from 1901 until the 1920s. Natural wind-shear and early accounts of the occasional removal of branches for Christmas festivities mean height measurements do not provide a reliable surrogate estimate. The two basal cores that could have helped provide definite answers failed to reach the centre due to the basal branching making precise coring alignment difficult. Using the curvature of the inner tree-rings (Norton et al. 1987), the missing radius in the cores was estimated, but suggest an age considerably later than 1901. Basically, the tree-ring samples show that the tree has grown at the rate of approximately $1 \mathrm{~cm}$ in diameter every year for the last 70 years (note Table 1 shows the mean radial growth, which is $4.35 \mathrm{~mm}$ ). Therefore, either the growth rate of the tree was significantly slower for several decades when it was first established (something not normally observed in open natural stands where growth rates tend to be relatively fast) or this tree established later than reported. Only a basal core to the pith of the tree can help resolve this issue.

Comparisons of the measured growth rate with three other locations in the natural range of Sitka spruce show the Campbell Island tree is growing exceptionally well (Table 1). Despite the faster growth rate, other aspects such as the Gini coefficient (Biondi \& Qeadan 2008) and autocorrelation appear similar. The Gini coefficient of inequality is used as an all-lag measure of diversity in tree-ring records; lower values indicate lower diversity and would not normally be preferred for palaeoclimate reconstructions. The fast growth rate does show the Campbell Island tree is thriving at this location and supports questions around the reported 1901 establishment date. Comparisons to three other planted trees located much further north in the North Island of New Zealand (Table 1b) show generally faster growth rates that follow the widely-observed pattern for rapid growth of introduced conifers (Ledgard 2004).

The bootstrapped response function analysis results (Fig. 2) show a classic high-latitude seasonal temperature response starting with predominantly inverse correlations with winter temperatures then gradually changing to significant 


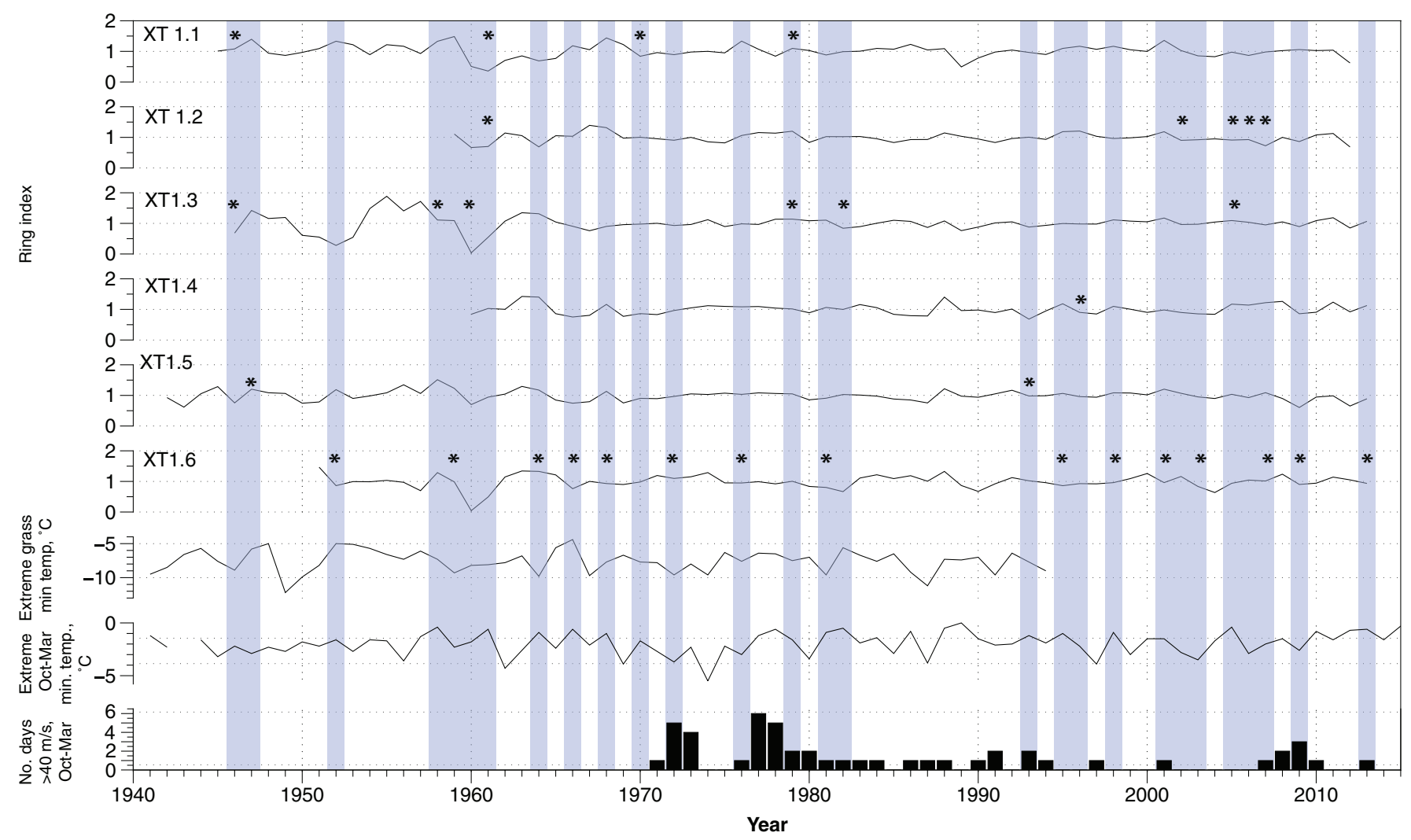

Figure 4. Tree-ring measurements from the Campbell Island Sitka spruce with key climate parameters of extreme minimum temperatures and gale force winds during the growing season (October-March) recorded at the meteorological station in Perseverance Harbour. Asterisks denote TRDs in individual tree series; blue columns identify periods of TRDs across the full dataset.

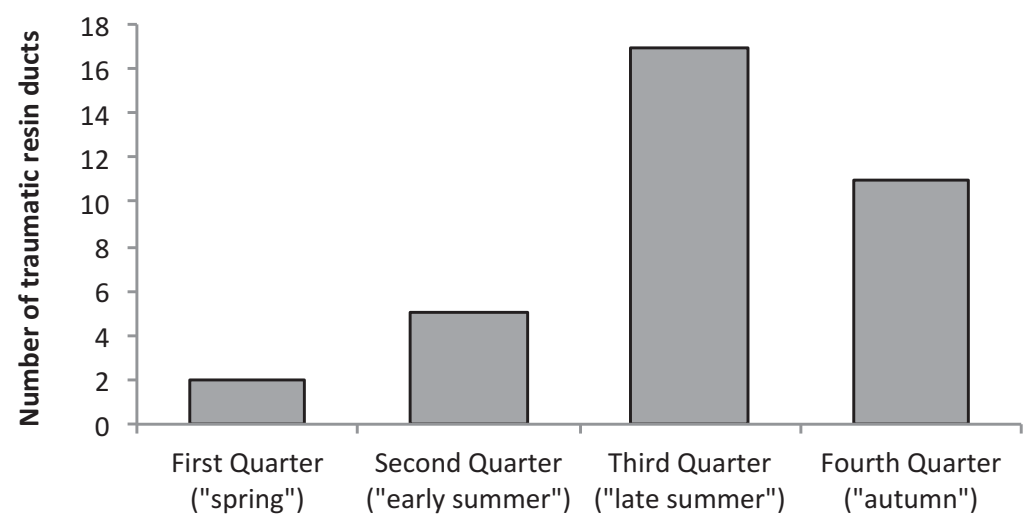

Growing season (divided into quarters)

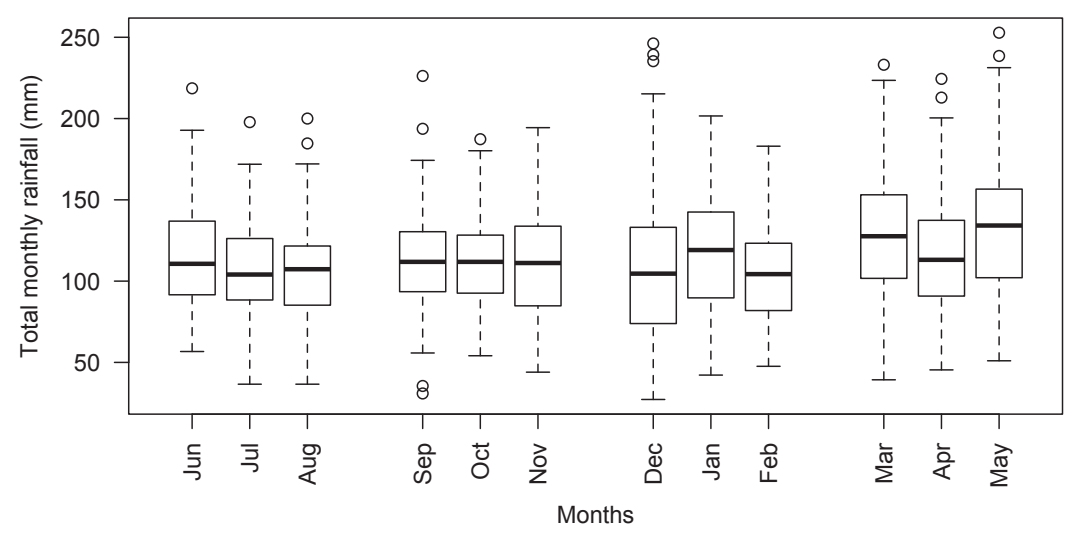

Figure 5. The 35 TRDs observed in the core samples stratified by their seasonal growth position. The exact position of a TRD relative to the respective total ring-width was calculated so that it could then be allotted into one of four growth quarters thought to be seasonal representations of spring through to autumn.

Figure 6. Box and whisker plots of recorded monthly rainfall since 1941 from Campbell Island. The months are clustered into seasons starting with austral winter (i.e. June-August) through to autumn (March-May). Outliers are indicated as open circles and defined as a data point that is located outside the fences (whiskers) of the boxplot (e.g. outside 1.5 times the interquartile range above the upper quartile and below the lower quartile) (R Core Team 2015). 


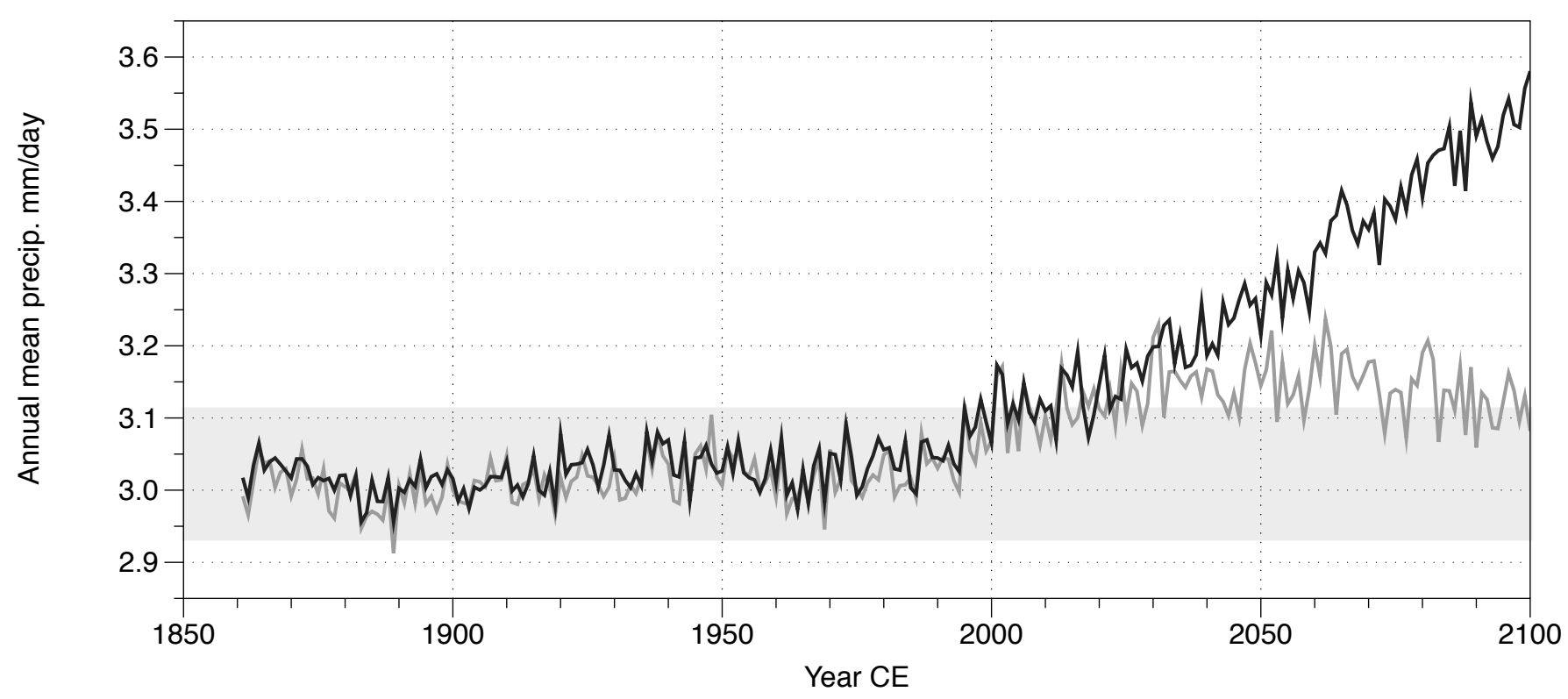

Figure 7. Annual (July-June) mean Coupled Model Intercomparison Project 5 (CMIP5) precipitation values for $50-55^{\circ} \mathrm{S}, 167-172^{\circ} \mathrm{E}$ for Representative Concentration Pathways (RCP) of 2.6 (low; dark grey line) and 8.5 (high; black line) emission scenarios. The light grey zone defines $2 \sigma$ range for RCP 2.6 over the period CE 1861-2015.

positive correlations with summer temperatures $(90 \%$ confidence) during December and January. Response function analysis is normally done using a collection of trees so our result must be interpreted as provisional or only indicative; however, the tree does appear to respond positively to warmer summers.

Even though the Campbell Island Sitka spruce is growing well, the observed presence of TRDs through the tree-ring series indicate that there are periods of stress. One possibility is that they are caused by extreme low temperatures (below $0^{\circ} \mathrm{C}$ ) during the growing season, when the cambium is active and secondary wall thickening and lignification of immature xylem cells in the annual ring are not yet complete (LaMarche \& Hirschboeck 1984; Bräuning et al. 2016), producing frost rings. Such frost damage provides a measure of extreme climatic change (Wimmer 2002) and has been used as a tool to reconstruct the past occurrences of cold events during the growing season. However, the fact that the local instrumental record does not demonstrate an alignment of frost events during the growing season with the TRDs in the tree and the extensive sheltering network of branching from virtually ground level, means extreme cold is an unlikely cause. A more probable explanation is from severe wind gusts creating torsion and bending of both branches and roots. The Campbell Island instrumental wind record (since 1972) contains some daily measurements of wind speeds during the growing season greater than $40 \mathrm{~m} \mathrm{~s}^{-1}$ (>144 $\left.\mathrm{km} \mathrm{hr}^{-1}\right)$.

The occurrence of TRDs in the individual cores (Fig. 4) shows that they did not all respond uniformly to the same events and that the basal core taken from a northerly aspect (i.e. XT1.6) had endured the greatest number of such events. Neither result is particularly surprising as coring heights and orientations varied. The distribution of events over time appears relatively uniform with the exception of a gap during the mid1980 s to early 1990s. Comparisons to local instrumental records did not reveal any obvious relationships (Fig. 4, lower panels) to extreme minimum temperatures or peaks in the number of days of recorded frosts. However, there were obvious periods during which there were gale force winds, as shown by the record of the number of days during which winds exceeded $40 \mathrm{~m} \mathrm{~s}^{-1}$ in the austral growing season of October to April (Fig. 4, bottom panel; note meteorological observations of this parameter are only available from 1972).

TRDs along the inner position of a tree ring is associated with a stress event occurring in spring after initiation of cambial activity (Fritts 1976). TRDs near the outer boundary of the ring are associated with a stressful event late in the growing season before the cambium becomes dormant. The 35 TRDs observed in the core samples were stratified by their seasonal growth position (Fig. 5). The exact position of each TRD relative to the total ring-width was calculated so that it could then be allotted into one of four growth quarters from spring through to autumn. The result clearly shows the occurrence of TRDs was predominantly in the late summer and autumn and not recorded evenly through the growing season. We do not observe a long-term trend in the occurrence of TRDs or parallel changes in extreme minimum temperatures (annual or October-March) or wind gusts recorded at the meteorological station(Fig. 5). Further investigation is needed into the direction and response of the tree to extreme events.

A key concern regarding alien plants on remote nature reserves is their ability to become invasive through seeding or vegetative spread and to displace the natural vegetation. This threat may be increased by enhanced meridional airflow across the region, as has occurred in the late 20th century (Turney et al. 2015), and through the Holocene (McGlone et al. 1997; Turney et al. 2016). During our two sampling trips to Campbell Island we did not observe any cones on the Sitka spruce tree nor on the surrounding ground. Similarly, there are no other reports of coning during previous visits (Meurk 1977; Meurk et al. 1994). This is unusual as Sitka spruce is monoecious (having both male and female strobili, or cones) and self-compatible so trees usually begin bearing cones between 20-40 years (El-Kassaby \& Reynolds 1990). Clearly the tree is old enough to be reproductively mature and produce cones. The absence of cone production may be 
a result of the rapid radial-growth rate that is delaying tree maturity; once the growth rate declines then cone production may begin. One important prediction of life-history theories is that trees should show a prolonged juvenile period, particularly in environments where early allocation to reproduction would come at high cost to future growth and reproduction (Thomas 2011). Perhaps in this case, the wind shear across the island has limited height growth which in turn has kept the tree in a pre-reproductive phase.

Even when male or female strobili begin to occur, viable seeds may not be produced. For instance, El-Kassaby and Reynolds (1990) showed poor rates of seed production were normal due mainly to female strobili receptivity occurring prior to male strobili dehiscence - especially likely when there is only one tree and so cross-pollination from trees at different stages is not possible. Another aspect to consider is that seeds are relatively small and their dispersal begins in autumn through to the following spring with the cones opening during periods of dry weather and reclose during wet weather (Malcolm 1987). For Campbell Island, the rainfall record (Fig. 6) shows a persistent and uniform level of rainfall and humidity throughout the year. Therefore, it appears highly unlikely that conditions are sufficiently dry for long enough to enable seed dispersal to occur, consistent with other recent studies suggesting not all IAS are viable on subantarctic islands (Williams et al. 2016).

Assuming the Campbell Island Sitka spruce produces viable cones in the future, we investigated the Intergovernmental Panel on Climate Change Representative Concentration Pathway (RCP) 2.6 (low emission) and 8.5 (high-emission) scenarios for the end of the 21st century (IPCC 2013). Extracting the annual mean CMIP5 precipitation values for the region (Taylor et al. 2011), we find a trend towards increasing rainfall across the region under both scenarios (Fig. 7). This trajectory appears robust (Knutti \& Sedlacek 2013), most probably a consequence of enhanced westerly airflow delivering moisture-laden airmasses over Campbell Island (Jones et al. 2016). With a trend towards increasingly wet conditions under a range of emission scenarios, it seems unlikely that seed dispersal will be possible. Therefore, we consider the invasive threat from this individual tree to be small; however, given the high-growth rate during the later 20th century, continued monitoring, as has happened in the past, will be prudent, and appropriate action taken if there is a change in the threat status. In the meantime, the tree continues to have important historic and tourist values.

\section{Acknowledgements}

Our thanks to the captain and crew of the MV Akademik Shokalskiy, and Henk Haazen and Kali Kahn on the Tiama for help in the field. This work was supported by the Australasian Antarctic Expedition 2013-2014, the Australian Research Council (FL100100195, FT120100004, and DP130104156) and the University of New South Wales. SJR and JMW were supported by SSIF funding for Crown Research Institutes from the New Zealand Ministry of Business, Innovation and Employment's Science and Innovation Group. Research on the New Zealand subantarctic Campbell Island was undertaken under Department of Conservation National Authorisation Numbers 37687-FAU and 39761-RES. We greatly appreciated historical information provided by Norm Judd. We thank Colin Meurk, an anonymous reviewer and the editor for their comments and help with improving this article.

\section{References}

Anonymous 1974. L'arbre du Ténéré est mort. Bois et Forêt des Tropiques 153: 61-65.

Biondi F, Qeadan F 2008. Inequality in paleorecords. Ecology 89: 1056-1067.

Bräuning A, Dimitrov DP, Gärtner H, Zafirov N, GarcíaGonzález I, De Ridder M 2016. Tree-ring features: indicators of extreme event impacts. IAWA Journal 37: 206-231.

Bunn AG 2008. A dendrochronology program library in $\mathrm{R}$ (dplR). Dendrochronologia 26: 115-124.

Bunn AG 2010. Statistical and visual crossdating in R using the dplR library. Dendrochronologia 28: 251-258.

Chown SL, Huiskes AH, Gremmen NJ, Lee JE, Terauds A, Crosbie K, Frenot Y, Hughes KA, Imura S, Kiefer K 2012. Continent-wide risk assessment for the establishment of nonindigenous species in Antarctica. Proceedings of the National Academy of Sciences 109: 4938-4943.

Early R, Bradley BA, Dukes JS, Lawler JJ, Olden JD, Blumenthal DM, Gonzalez P, Grosholz ED, Ibañez I, Miller LP, Sorte CJB, Tatem AJ 2016. Global threats from invasive alien species in the twenty-first century and national response capacities. Nature Communications 7: 12485 .

El-Kassaby YA, Reynolds S 1990. Reproductive phenology, parental balance, and supplemental mass pollination in a Sitka-spruce seed-orchard. Forest Ecology and Management 31: 45-54.

Frenot Y, Chown SL, Whinam J, Selkirk PM, Convey P, Skotnicki M, Bergstrom DM2005. Biological invasions in the Antarctic: extent, impacts and implications. Biological Reviews 80: 45-72.

Friedman JH 1984. Avariable span smoother. (No. LCS-TR-5). Stanford Univ CA lab for computational statistics.

Fritts HC 1976. Tree rings and climate. New York, Academic Press.

Gregory MR2009. Environmental implications of plastic debris in marine settings - entanglement, ingestion, smothering, hangers-on, hitch-hiking and alien invasions. Philosophical Transactions of the Royal Society of London B: Biological Sciences 364: 2013-2025.

Grissino-Mayer HD 1993. An updated list of species used in tree-ring research. Tree-ring Bulletin 53: 17-43.

Gurskaya M, Moiseev P, Wilmking M 2016. Does slope exposure affect frost ring formation in Picea obovata growing at treeline in the Southern Urals? Silva Fennica 50: $1-19$.

Harlow WM, Harrar ES 1968. Textbook of dendrology. New York, McGraw-Hill Book Company Inc. 512 p.

Harsch MA, McGlone MS, Wilmshurst J 2014. Winter climate limits subantarctic low forest growth and establishment. PLoS one 9: p.e93241.

Hughes KA, Convey P 2012. Determining the native/nonnative status of newly discovered terrestrial and freshwater species in Antarctica - current knowledge, methodology and management action. Journal of Environmental Management 93: 52-66.

IPCC 2013. Climate change 2013: the physical science basis. Contribution of working group I to the fifth assessment report of the intergovernmental panel on climate change. In: Stocker TF, Qin D, Plattner G-K, Tignor M, Allen SK, Boschung J, Nauels A, Xia Y, Bex V, Midgley PM eds. Fifth assessment report of the intergovernmental panel on 
climate change. Cambridge, United Kingdom and New York, USA, Cambridge University Press. Pp. 1-1535.

IUCN 2016. Invasive species. www.iucn.org/theme/species/ our-work/invasive-species (accessed 22 October 2016).

Jones JM, Gille ST, Goosse H, Abram NJ, Canziani PO, Charman DJ, Clem KR, Crosta X, de Lavergne C, Eisenman I, England MH, Fogt RL, Frankcombe LM, Marshall GJ, Masson-Delmotte V, Morrison AK, Orsi AJ, Raphael MN, Renwick JA, Schneider DP, Simpkins GR, Steig EJ, Stenni B, Swingedouw D, Vance TR 2016. Assessing recent trends in high-latitude southern hemisphere surface climate. Nature Climate Change 6: 917-926.

Knutti R, Sedlacek J 2013. Robustness and uncertainties in the new CMIP5 climate model projections. Nature Climate Change 3: 369-373.

Kueffer C, Daehler CC, Torres-Santana CW, Lavergne C, Meyer J-Y, Otto R, Silva L 2010. A global comparison of plant invasions on oceanic islands. Perspectives in Plant Ecology, Evolution and Systematics 12: 145-161.

LaMarche VC, Hirschboeck KK 1984. Frost rings in trees as records of major volcanic eruptions. Nature 307: 121-126.

Lebouvier M, Laparie M, Hulle M, Marais A, Cozic Y, Lalouette L, Vernon P, Candresse T, Frenot Y, Renault D 2011. The significance of the sub-Antarctic Kerguelen Islands for the assessment of the vulnerability of native communities to climate change, alien insect invasions and plant viruses. Biological Invasions 13: 1195-1208.

Ledgard N 2004. Wilding conifers - New Zealand history and research background. In: Hill RL, Zydenbox SM, Bezar $\mathrm{CM}$ eds. Managing wilding conifers in New Zealand present and future. Lincoln, NZ, Zealand Plant Protection Society. Pp. 1-25.

Lee JE, Chown SL 2009. Breaching the dispersal barrier to invasion: quantification and management. Ecological Applications 19: 1944-1959.

McGeoch MA, Butchart SH, Spear D, Marais E, Kleynhans EJ, Symes A, Chanson J, Hoffmann M2010. Global indicators of biological invasion: species numbers, biodiversity impact and policy responses. Diversity and Distributions 16: 95-108.

McGeoch MA, Shaw JD, Terauds A, Lee JE, Chown SL 2015. Monitoring biological invasion across the broader Antarctic: a baseline and indicator framework. Global Environmental Change 32: 108-125.

McGlone MS, MoarNT, Wardle P, Meurk CD 1997. Late-glacial and Holocene vegetation and environment of Campbell Island, far southern New Zealand. The Holocene 7: 1-12.

Malcolm DC 1987. Some ecological aspects of Sitka spruce. Proceedings of the Royal Society of Edinburgh 93B: 85-92.

Meurk CD 1977. Alien plants in Campbell Island's changing vegetation. Mauri ora 5: 93-118.

Meurk CD, Given DR 1990. Vegetation Map of Campbell Island. Scale 1:25000. Map (1 sheet). DSIR Land Resources. Christchurch, New Zealand, Department of Scientific and Industrial Research.

Meurk CD, Foggo MN, Wilson JB 1994. The vegetation of subantarctic Campbell Island. New Zealand Journal of Ecology 18: 123-168.

Nikula R, Fraser C, Spencer H, Waters J 2010. Circumpolar dispersal by rafting in two subantarctic kelp-dwelling crustaceans. Marine Ecology Progress Series 405: 221-230.

Norton DA, Palmer JG, Ogden J 1987. Dendroecological studies in New Zealand 1. An evaluation of tree age estimates based on increment cores. New Zealand Journal of Botany 25: 373-383.

R Core Team 2015. R: a language and environment for statistical computing. Version 3.4.1. Vienna, Austria, R Foundation for Statistical Computing. www.R-project.org.

Richardson DM 1998. Forestry trees as invasive aliens. Conservation Biology 12: 18-26.

Schweingruber FH 2007. Wood structure and environment. Springer Science \& Business Media. 279 p.

Stoffel M, Bollschweiler M, Butler DR, Luckman BH (eds.) 2010. Tree rings and natural hazards: a state-of-the-art. Springer Netherlands. $505 \mathrm{p}$.

Stokes MA, Smiley TL 1968. An introduction to tree-ring dating. Chicago, USA, The University of Chicago Press. $73 \mathrm{p}$.

Taylor KE, Stouffer RJ, Meehl GA2011. An overview ofCMIP5 and the experiment design. Bulletin of the American Meteorological Society 93: 485-498.

Thomas SC 2011. Age-related changes in tree growth and functional biology: the role of reproduction. In: Meinzer FC, Lachenbruch B, Dawson TE eds. Size-and age-related changes in tree structure and function. Dordrecht, Springer Netherlands. Pp. 33-64.

Turney CSM, Fogwill CJ, Klekociuk AR, van Ommen TD, Curran MAJ, Moy AD, Palmer JG 2015. Tropical and mid-latitude forcing of continental Antarctic temperatures. The Cryosphere 9: 2405-2415.

Turney CSM, Fogwill CJ, Palmer JG, van Sebille E, Thomas Z, McGlone M, Richardson S, Wilmshurst JM, Fenwick P, Zunz V, Goosse H, Wilson KJ, Carter L, Lipson M, Jones RT, Harsch M, Clark G, Marzinelli E, Rogers T, Rainsley E, Ciasto L, Waterman S, Thomas ER, Visbeck M 2017. Tropical forcing of increased Southern Ocean climate variability revealed by a 140-year subantarctic temperature reconstruction. Climate of the Past 13: 231-248.

Turney CSM, Jones RT, Fogwill C, Hatton J, Williams AN, Hogg A, Thomas ZA, Palmer J, Mooney S, Reimer RW 2016. A 250-year periodicity in Southern Hemisphere westerly winds over the last 2600 years. Climate of the Past 12: 189-200.

Walther G-R, Roques A, Hulme PE, Sykes MT, Pyšek P, Kühn I, Zobel M, Bacher S, Botta-Dukát Z, Bugmann H, Czúcz B, Dauber J, Hickler T, Jarošík V, Kenis M, Klotz S, Minchin D, Moora M, Nentwig W, Ott J, Panov VE, Reineking B, Robinet C, Semenchenko V, Solarz W, Thuiller W, Vilà M, Vohland K, Settele J 2009. Alien species in a warmer world: risks and opportunities. Trends in Ecology \& Evolution 24: 686-693.

Whittaker RJ, Fernández-Palacios JM 2007. Island biogeography: ecology, evolution, and conservation. UK, Oxford University Press. $401 \mathrm{p}$.

Wimmer R 2002. Wood anatomical features in tree-rings as indicators of environmental change. Dendrochronologia 20: $21-36$.

Wimmer R, Grabner M 1997. Effects of climate on vertical resin duct density and radial growth of Norway spruce [Picea abies (L.) Karst.]. Trees-Structure and Function 11: 271-276.

Williams LK, Kristiansen P, Sindel BM, Wilson SC, Shaw JD 2016. Quantifying the seed bank of an invasive grass in the sub-Antarctic: seed density, depth, persistence and viability. Biological Invasions 18: 2093-2106.

Wilmshurst JM, McGlone MS, Turney CSM 2015. Longterm ecology resolves the timing, region of origin, and 
process of establishment for a disputed alien tree. AoB Plants 7: plv104.

Zang C, Biondi F 2013. Dendroclimatic calibration in R: the bootRes package for response and correlation function analysis. Dendrochronologia 31: 68-74.

Editorial board member: Tim Curran

Received 11 November 2016; accepted 5 July 2017 